This article is available open access under a CC BY-ND 4.0 license as part of Berghahn Open Anthro, a subscribe-to-open model for APC-free open access made possible by the journal's subscribers.

\title{
Post-Hellenistic Perspectives ON DIVINATION, THE INDIVIDUAL, AND THE COSMOS
}

Elsa Giovanna Simonetti

\begin{abstract}
This article investigates the relation between ancient divinatory theories and ontological assumptions about individuals, the gods, and the cosmos through the writings of Dio Chrysostom, Epictetus, and Maximus of Tyre-three philosophers who belong to the first Roman imperial age. By exploring their works in light of recent anthropological studies, this article will discuss how different divinatory systems generate, and are embedded in, specific ontologies. All three writers analyze divination as a means to bridge contingency and transcendence and to situate individuals within the cosmos. As such, their analysis of divination relates to specific ontological systems: a mono-ontology reducible to one divinematerial principle for Epictetus, and the poly-ontology of a graduated cosmos for Dio Chrysostom and Maximus of Tyre.
\end{abstract}

Keywords: antiquity, Cynicism, divination, ontology, Platonism, Stoicism

Philosophical reflection in the Roman early imperial age encompassed all aspects of human experience, from socio-political issues and scientific problems to religious questions and moral reflections. Since divination was a key component of early imperial public and private life, it also constituted a subject fully worthy of philosophical investigation. This article will explore divination in the first centuries $\mathrm{AD}$ through the eyes of three philosophers and will reconstruct their privileged perspective as 'anthropologists of the ancient world'. It will analyze the conceptual structures of the divinatory theories presented by first-hand witnesses and critics in light of modern anthropological findings in the field of ontology and divination. The objective is to show how ontological assumptions 
shaped the divinatory doctrines developed by intellectuals in the early imperial age, and to examine the complex interrelation between transcendence and contingency that they imply.

Recent anthropological studies have explored divination, as well as other human activities and beliefs, in terms of the ontological systems and assumptions on which they rest. Some of these studies are directly relevant for the present analysis of ancient divinatory theories. Pascal Boyer and Philippe Descola focus mostly on the cognitive-physicalist aspects of ontological theories and the relation between problems of mind and cognition, on the one hand, and culturally determined sets of ideas and representations, on the other-an approach recently presented by Peter Struck (2016) in the field of classics. In an article titled "Why Divination?" Boyer (2020) explores the relations among the participants of divinatory sessions. In light of his study of cognition, divination's practices, and their epistemic foundations, he proposes the concept of 'ostensive detachment' as the key requisite for the reliability of a diviner's statements and activity. In this view, ontological theories constitute post hoc explanations for divination rather than guiding assumptions. Philippe Descola's (2013) Beyond Nature and Culture also grounds ontology in theories of cognition, but in contrast to Boyer, Descola sees ontology as the basis for socio-cultural practices. Building on Boyer and Descola, the contributors to this special issue explore the ways in which ontologies impact divinatory practice. One particular question in this regard is the connection between ontology and cosmology. Below I will retrace the arguments of three ancient philosopher-anthropologists on this relation and how it determines important aspects of divinatory logics. ${ }^{1}$

Two important caveats are in order at this point. First, 'ontology' in this context is used primarily in its anthropological, and not in its philosophical, meanings. Second, in every single situation, there may be one or many ontological systems at work. David Zeitlyn mentions both of these qualifications in his contribution to this issue, and his call for a focus on the epistemology and pragmatics of divination is very useful (see also Zeitlyn 2009). Concretely, Zeitlyn (2001) directs his attention to the dialogic exchanges between diviners and their clients, and as we will see shortly, this resonates with ancient philosophical debates on the technically and ethically ideal or 'correct' kind of consultation. Zeitlyn (this issue) also warns against the attachment of one ontology to one kind of divination; instead, we should look for particular and different combinations of ontologies and ontological systems in particular divinatory practices. In this regard, Michael Scott's (2007) The Severed Snake is particularly useful. Scott opposes the poly-ontology of the Arosi to the monoontology of Christianity - an antithesis that can be applied to Platonism and Stoicism, respectively, and is immediately relevant for crucial distinctions in divinatory systems, as we will see below. While mono-ontology "assume[s] the consubstantiality of all things as a result of their common origin" (ibid.: 10), 
poly-ontology, which represents the system of the Arosi, is instead "any cosmology that posits two or more fundamental and independently arising categories of being" (ibid.: 12).

Zeitlyn's and Scott's approaches attest to the importance of the interaction between transcendent and contingent factors for the study of divinatory theories. How do practical dynamics and contingent arrangements in divinatory sessions relate to broader ontological conceptions of the world and the agents operating in it? The present article will attempt to give an answer to this question by looking at the works of late-ancient philosophers, drawing on Zeitlyn's focus on pragmatic elements of divination and Scott's framework of monoand poly-ontologies. The main objective is to describe particular assumptions about the ontology of ancient observers underlying their reflections on divinatory practices. The term 'ontology' here is understood as a set of definitions and mutual relations that characterize different agents and forces, intended as 'beings' involved in the divinatory process.

The time frame chosen for this study is the first Roman imperial age (the first through second centuries AD) - a 'golden age' for divination, whose widespread success stimulates intellectuals to reflect deeply on its ontological and phenomenological dimensions. During this era, the impressive diversification of divinatory practices and the rise of new professional figures in the field of prophecy have a destabilizing impact on divination's traditional social-normative role. An increasing number of seers and thaumaturges, detached from official oracular temples, travel up to the most remote peripheries of the Empire, responding to the widespread desire for a personal, intimate relationship with the divine. ${ }^{2}$ Some examples are the itinerant sage Apollonius of Tyana (first century AD), described by Flavius Philostratus (third century AD), a renowned 'divine man', who travels throughout the Mediterranean basin to India and Ethiopia, practicing divination, healing, and exorcism (cf. Philostr. VA.), and Alexander of Abonuteichos, who founds a new oracle centered around Glykon, a newly created serpent-god, as attested to by statues and coins, as well as by Lucian of Samosata's merciless portrait (cf. Luc. Alex). ${ }^{3}$

A 'tribe' of itinerant 'demonic' (daimonioi) or 'divine men' (theioi andres), often connected to 'Oriental' deities such as Cybele or Serapis (cf. Plut. De Pyth. or. 407C; Apul. Metam. 8.27-28; Lucian. De dea Syr. 1), offer their predictive-iatromantic skills for a fee (see Brown 1971; Flower 2008). 'Professionals of the supernatural' spread throughout the Roman empire, performing all sorts of divinatory deeds, ${ }^{4}$ ranging from Egyptian magical practices (e.g., the Greek Magical Papyri) to Chaldean astrological observations, while the activity of traditional oracular sites, such as Delphi, is slowly overshadowed by the Oriental shrines of Didyma and Claros.

Dream interpretation also acquires an important role in this age. Artemidorus of Daldis's On Dreams (Oneirocritica, second century AD) provides a 
coherent and accessible body of technical concepts and pragmatic instructions for deciphering dreams. This was certainly not an isolated case, given the myriad of experienced professionals, handbooks, and repertoires that Artemidorus admits to having consulted when gathering first-hand data on emperors such as Caracalla (cf. Herod. Div. Marc. 6.8.3), as attested by Aelius Aristides's for his tractate (Artem. Oneir. 1.40-60). Incubatory temples host flocks of pilgrims, including Divine speeches (Hieroi logoi) a dream-diary in which he keeps track of his personal relationship with the god Asclepius.

This lively prophetic panorama stimulates intellectuals such as Dio Chrysostom, Epictetus, and Maximus of Tyre to explore the validity and usefulness of divinatory practices, to which always more private citizens resort in order to receive individual support and guidance (see, e.g., De E 386C; De Pyth. or. 408C). Their philosophical analysis of the ontological status of divination expands to include the nature and structure of the universe, the role of humans in a precise cosmological system, and the forces of providence, fate, fortune, and individual responsibility. As Susanne Bobzien (1998: 146) clearly puts it, "virtually all philosophical schools, sects and currents in the 1st and 2nd century A.D. ... had developed their own position on fate and that which depends on us."

Quite surprisingly, Dio Chrysostom, Epictetus, and Maximus of Tyre all argue for a strong compatibility, if not an equivalence, between divination and 'ordinary' or 'rational' ways of knowledge acquisition. ${ }^{5}$ So why do we need divination if it is supposed to achieve exactly the same results as individual rational deliberation? Dio Chrysostom, despite his 'rationalistic' approach, seems to place great trust in the gods' supreme status and predictive powers. Epictetus, instead, underscores that divination and 'ordinary' cognition, despite often reaching for the same conclusions, have nevertheless two clearly separate domains of reference. Maximus of Tyre shows that divination has the unique power to connect the divine intellect and the human mind; it has a crucial role in writing and reading cosmic events, and even has the power to harmonize the entire cosmos.

The works in which Dio, Epictetus, and Maximus present their theories on divination belong to the genre of philosophical orations (dissertationes) speeches destined for classes of philosophy students (Epictetus) or for a wider audience, certainly including habitual clients of diviners (Maximus, Dio). The aim of these plain, accessible discourses, rich in elucidatory analogies and traditional exempla, is to stimulate moral-intellectual improvement on the part of the public and to promote the standards of philosophical life (philosophikos bios). It is now time to analyze what the chosen texts can tell us about the relation between ontology and divination, and to explore the previously unknown aspects of divination that the ontological dimension can reveal. The analysis of the three late ancient authors chosen for this article will greatly benefit from some key epistemic categories employed in modern anthropological studies. 
The first category is 'fallibility' - on the part of the diviner (for Dio Chrysostom and Epictetus), but also of the god her/himself (for Maximus of Tyre). This is emphasized by the fact that ancient oracles, almost by definition, talk in riddles, and is linked to the ontological relationships between gods and mortals. The second and third categories are 'agentive' forms of divination as opposed to 'calculatory' ones (an opposition outlined by William Matthews in the introduction). In the works discussed here, they follow from philosophical considerations of the relationship between them. All these elements will be highlighted in the present analysis in light of the different ontological theories formulated by our three thinkers, and on the basis of the articulation that they posit between transcendent laws and material events.

\section{Dio Chrysostom}

The Cynic philosopher Dio Chrysostom (ca. 40-ca. $120 \mathrm{AD}$ ) expresses his views on divination especially in Diogenes, a speech delivered in exile, while he was wandering in poverty throughout Asia Minor. This oration is constructed around the ambivalent meaning of the verb chrêsthai-which will significantly recur in Epictetus's text analyzed below (cf. Epict. Ench. 32.1-3 and infra). Chrêsthai means 'to use', but it is also the technical term for 'consulting an oracle'. As Diogenes argues, possessing something good requires being capable of using it properly. In a similar way, to consult (chrêsthai) a god-as well as another man, or even oneself (Dio Chrys. 10.17.3-4)-requires being capable of doing so appropriately and of making good use of the response obtained. In the opposite case, unpleasant consequences will follow.

Before going into the details of Dio's discourse, we should summarize some general information on his relation to divination. In The First Discourse on Kingship, Dio establishes a parallelism between the best forms of government, both divine and human. Zeus - the supreme god, creator, and ruler of the cosmos-is the perfect sovereign, who exerts his guidance, care, and providence (pronoia) on the whole world. In the context of this panegyric, Dio reports a peculiar experience that he had while traveling across the Peloponnese. He had lost his way, and in the forest he met a mysterious woman who claimed to have been awarded the power of prophecy (mantikê) from the Great Mother (Cybele). She predicted, not ravingly but with "self-control and moderation," that Dio's troubles would not last long (Dio Chrys. 1.54-56; trans. Cohoon 1932). While exposing to the rhetor some events of his future life, she indulged in more wideranging considerations on the nature of divination, describing it as a divine gift, superior to all ordinary human activities and affairs (Dio Chrys. 1.57). To the People of Alexandria confirms that Dio himself shares in this belief: the gods constantly help and support humankind, foretelling the future to them as well. 
No matter how a message is delivered, and whether or not it is clear, the god's intention is always to do good to humans and to reveal useful information to them (Dio Chrys. 32.13). ${ }^{6}$ Another proof of divine reliability comes from a discourse of Dio wherein he reports his autobiographical experience of receiving a divine suggestion at Delphi. Apollo urged Dio to persevere in his travels, a command he did not dare to disobey since "lying is a harsh thing to impute and not consistent with even a man's standards, to say nothing of a god's" (Dio Chrys. 13.10; trans. Cohoon 1932).

As these loci indeed confirm, Dio's gods do not lie. Divination is a reliable means to acquire information, especially about an individual's future. Divination is intrinsically 'Other': it comes from the divine dimension, is by definition non-deceptive, and is founded on the huge ontological gap between humankind and the gods, and on the moral and intellectual superiority of the latter. These features are also present in Diogenes, where Dio insists on the epistemic-linguistic - other than ontological-gap between humans and gods (10.24.1): the gods have their own language (10.23.5), resulting in the apparently deceptive character of their statements. As we will see, Epictetus and Maximus will argue in favor of a different view - that there is a close, almost familiar connection between humankind and the gods that justifies their reciprocal interaction and communication.

From his perspective of irreverent Cynicism, Dio flashes back into classical antiquity, where he finds a series of illustrious, well-known topoi (some shared by Maximus himself). The most striking one is the case of Laius, Oedipus's father, who misunderstood the advice of the Delphic oracle. He 'resorted to the god' (see the reference to chrêsthai above) without being capable of 'making good use' of him, and therefore failed to understand his suggestion. The response indeed runs as "not to beget, or, having begotten, to expose" (Dio Chrys. 10.25; trans. Cohoon 1932). This sentence can be read in two ways: (1) not to conceive a child $(\neg A)$, or, if the child is conceived $(A)$, to expose $(B)$; (2) not to conceive a child $(\neg A)$, or, if the child is conceived $(A)$, not to expose $(\neg B)$. The right command was meant to be: $\neg A \vee(A \rightarrow \neg B)$, while Laius wrongly interpreted it as: $\neg A \vee(A \rightarrow B)$. In other words, the negation was to be applied to both the statement $A$ and the eventual consequence $B$. Based on this logical misunderstanding of the oracular instruction, Laius underwent terrible sufferings: his son Oedipus killed him and married his wife (Oedipus's own mother Jocasta), and his whole household was destroyed (10.25-26). The moral lesson that Dio suggests here is that, without the correct hermeneutic tools, truth becomes an extremely dangerous burden to carry. ${ }^{?}$

Especially the argumentative core of Dio's oration proves that misunderstandings and misuses like the one committed by Laius have an ontological basis, and that Dio's greatest concern is in fact the ontological dimension of divination. As Dio explains, we cannot make use of something (an object, a 
human being, a god) if we do not know what it is - that is, if we do not know its ontological status or dimension. It is impossible to make use of oneself without knowing oneself (Dio Chrys. 10.22). The maxim 'Know thyself' is also significantly inscribed on the Delphic temple. Self-knowledge is the prerequisite for approaching the oracle, as well as for 'using' other human beings-a greater and more difficult task (Dio Chrys. 10.21-22). We could infer from this series of arguments that to properly consult a god would require knowing the god, and thus being in possession of solid theological knowledge. But Dio does not go this far.

Dio's focus is epistemic rather than theological: just like a modern anthropologist, he inquires into the reasons that led to the failure of the divinatory act, one of which is 'deception'. Yet according to Dio, neither the gods nor the soothsayer deceive the inquirer. Rather, the inquirer is self-deceived, due to her/ his own lack of self-knowledge, which prevents a correct understanding of the divine message and a good use of it. Dio suggests that the perfect consultant is a philosopher, someone who has reached for complete self-knowledge and for a full understanding of his/her own ontological position as a human being in the world, which is separate from and greatly inferior to the one occupied by the gods. Thus, the epistemological problem identified by Dio leads him to particular conclusions about ontology. Only philosophers are fully aware of the interpretative difficulties posed by messages coming from the divine, that is, from another ontological dimension. As for the importance of self-knowledge, Michael Puett's (2002) discussions on self-cultivation and on self-knowledge as a process of ontological change can be useful in this respect, in light of his broader understanding of the relationship between the human and the divine sphere in early China. The value that Puett places on knowing oneself as a human beingas being separated and different from the gods, and belonging to a different existential plan-is analogous to Dio's insistence on the need for the inquirer to know her/his place in the cosmos in order to make the divinatory act effective.

\section{Epictetus}

Epictetus (ca. 50-ca. $135 \mathrm{AD}$ ), along with Seneca and Marcus Aurelius, is among the crucial protagonists of the revival of Stoic philosophy in Rome. One of his Dissertationes concentrates on "How we should make use of divination" (Epict. Diss. 2.7).$^{8}$ Epictetus's ideas on divination generally align with those of other imperial Stoics. He attacks academics for their skeptical epistemological approach, which would impair any divinatory activity (Epict. Diss. 2.20.27-29; cf. Opsomer 1997: 21), and endorses a Stoic monistic-materialistic worldview based on the power of the pneûma, a material-divine force that permeates the cosmos and interconnects all beings-humans and gods-through reciprocal sympathetic relations. 
In "How we should make use of divination," Epictetus explains divination in light of his monistic cosmological conception. The cosmos has a rational foundation and an ordered structure in which every event results from a predetermined series of causes. In this framework, divination is the art (technê) or science (epistêmê) (cf. [SVF 654] Stob. 2.67.13) ${ }^{9}$ that examines and formulates 'universal theorems' connecting a given sign with its future outcome (in the form of an inference: if $x \rightarrow$ then $y$ ), ${ }^{10}$ based on the Stoic assumption that "whatever happens, it is a sign of something that will happen" (Sen. NQ 2.32.4; trans. Corcoran 1971). The Stoics posit an ontological-epistemological co-implication between the existence of divination and that of caring, provident deities, who help us find our way by means of symbols that indicate the future distributed throughout the cosmos. This idea can be qualified as an example of 'calculatory' divination, as the gods cannot deceive, different from the 'agentive' types described by Dio and Maximus, and it resonates with Olaf Almqvist's argument (this issue) that the Stoic gods (as opposed to Homeric deities) are absolutely truthful in divination.

In a homogeneous ontological system in which all contingent events are interconnected and presided over by divine intelligence, what is the place for human choice and initiative? This is the main concern of Epictetus's "Of the things which are under our control and not under our control” (Epict. Diss. 1.1), where he tries to reconcile a deterministic worldview with the notion of human freedom and responsibility (1.1.1-2). The process of rational deliberation, he argues, is strictly individual: it involves personal ethical choices that shape our character. This proves that human ethical behavior is not predetermined by fate. Thus, if we are in control of our actions, Epictetus asks, why do we often feel the need to consult oracles and seers? Because, he explains, we are influenced by unhealthy passions, such as cowardice and fear of the future (Epict. Diss. 2.7.9), which lead us to query diviners about inappropriate topics on the wrong occasions. Epictetus's view of divination as a sort of psychological consolation certainly resonates with Evans-Pritchard's ([1937] 1976: 22-23) idea that the witchcraft mentality allows humans to answer the existential question 'why me?' and thus-by giving a sense of meaning and reassurance-helps us to cope with the evils and tragedies of existence.

Nevertheless, Epictetus sides with an opposite conception of divination, one that deals with pertinent issues, requires a correct mental attitude, and is defined by reasonable expectations. With regard to the content of divination, the only legitimate object of inquiry, and the diviner's sole area of expertise, these are things that are 'not in our power', that we cannot control or change and are 'not up to us' (ouk eph'hêmin) - a technical expression that is part of the specialist lexicon adopted in debates on fate and human freedom that, as mentioned in the introduction, blooms in the first centuries AD. ${ }^{11}$ Epictetus, in another of his speeches (1.22), explains in further detail that things 'not up to 
us' are those that pertain to our body (which does not properly belong to us), material possessions, and everyone surrounding us, from our closer relatives to the entire country and beyond. Since we cannot control any of these, they are not per se good or bad, but 'indifferent' (adiaphora, according to the Stoic technical terminology). Indifferents can be employed in constructive or destructive ways, as effectively explained by Epictetus in his Handbook: "Everything has two handles, by one of which it ought to be carried and by the other not" (Epict. Ench. 43.61; trans. Oldfather 1928).

The ontological domain of divination is limited to the indifferents. And since the content of divinatory responses does not depend on us, and therefore cannot be qualified as either good or bad, divination itself is an indifferent (Epict. Ench. 32.1-3). The only thing completely in our power is indeed our acceptance of impressions and rational deliberation (proairesis), which determines the moral quality of our actions. Our deliberations are certainly inscribed in fate and providence, but divination cannot foresee them (Epict. Diss. 1.1.713). Thus, it makes no sense to ask the diviner about 'that which is up to us', about things that fall within the sphere of our own moral choices. There is only one special diviner that can guide us on such issues: a natural inner prophet (mantis), ontologically connected to us and ideally located within our soul, which provides us with moral suggestions as a sort of voice of consciousness.

That being said, what is the correct mental attitude when consulting a diviner? A state of serenity and lack of expectations, Epictetus maintains, since whatever the response might be, it will not affect the sphere of individual ethical choices, moral character, and integrity. The role of the inquirer is to make good use (chrêsasthai kalôs) ${ }^{12}$ of the prediction obtained: after receiving a response, taking a sensible course of action is one's own responsibility.

Divination merely reveals the development of fate, designed for us by a benevolent god. The seer simply anticipates the predetermined outcome of events, and gives us the opportunity to adapt and prepare so that we can act according to sound ethical principles when the moment comes. As Epictetus puts it: "What god and destiny reserve to you is the best for you" (Epict. Diss. 2.7.13; trans. Oldfather 1925). The gods, of which the diviner is an infallible representative and spokesperson, are reliable consultants and advisers, whose suggestions need to be respected and followed (Epict. Ench. 32.2-3), since every divine statement, once uttered, becomes an inescapable obligation. Epictetus postulates a wide ontological gap between the god (superior, omniscient, transcendent) and human beings. The seer or medium, an intermediate agent between the divine and the human plan, offers some glimpses into the divine and predetermined order of the cosmos.

Just like Dio, Epictetus stresses the sublime, ethically binding nature of the advice coming from the gods, and accounts for a prescriptive rather than predictive function of divination. For Epictetus, once we understand the forces 
that govern the universe, it becomes clear that the ontological realm of divination is that of the unchangeable-determined once and for all-and of morally indifferent things. The gods employ the communicative channel of divination to offer their support, care, and help to humans; wise and virtuous human beings can rely on an 'inner prophet', ontologically equivalent with their own faculty of moral discernment. Epictetus also explains how divination is practiced: it is based on inference from signs-a methodology that, when combined with a conception of fixed principles underlying fate, falls into the category of calculatory divination as defined in this issue. It concerns the outcomes of those events that cannot be disclosed by rational investigation (logos) or specialized knowledge (technê), from which it therefore differs. Stéphanie Homola and William Matthews in the present issue demonstrate that, in the case of calculatory divination, errors must be ascribed to the human operator of the system, not to the source of the prophetic sign. Epictetus would very well agree with this statement. He even talks of the inner prophet as an 'inner voice' expressing itself in cryptic symbols (sêmeia) (Epict. Diss. 2.7.3.5) that need decoding and technical interpretation.

As for agentive modalities of divination, they seem to be assumed in Dio (explicitly, when he talks about the priestess inspired by Cybele) and in Maximus, but no great attention is devoted to this specific issue by our three authors. Rather, insistence is placed again on the image of the perfect consultant, who for Epictetus, as well as for Dio, is the philosopher. The philosopher has a profound understanding of what divination is-of its essence ( $t i$ esti) and its ontological status. Philosophical knowledge allows for a profound understanding of the 'big picture', of the metaphysical and cosmological principles on which the world operates, and of the strands of causation at work in the cosmos.

\section{Maximus of Tyre}

In his oration Prophecy and Human Foresight, the Platonist rhetor Maximus of Tyre (ca. 125-ca. $180 \mathrm{AD}$ ) attempts to answer the question as to whether prophecy and human intelligence are compatible, while also dealing with the problematic relationship between fate and human free will. ${ }^{13}$ The most striking aspect of Maximus's theory is that he identifies divination (mantikê) with the divine intellect itself (nous theios) (Max. Or. 13.3.18). Moreover, he argues in favor of a substantial kinship between divine and human intellect (which are syngenes, or cognate), and, by borrowing an originally Stoic idea (cf. SVF 2.528-9; 638), he envisions the cosmos as a shared household inhabited by gods and humans. The assumption of an ontological continuity between human and divine beings in the cosmos justifies the similar nature and scope of human and divine predictive faculties, but some questions arise at this point. 
When should we resort to the capacities of human intellect, and when should we instead resort to the divine ones? Do human and divine intellect, although cognate, have different and hierarchically ordered epistemological statuses?

It is hard to give an answer to these questions, also in light of the fact that divination and rational prediction often happen to reach the exact same conclusion-which prevents an assessment $a$ posteriori. Maximus introduces the renowned example of Apollo's oracle to the Athenians when the Medians were approaching the polis. The Delphic god suggested that they used a 'wooden wall' for protection-a metaphor that, as interpreted by Themistocles, suggested that all the citizens should take refuge on the triremes. Maximus objects that if the Athenians consulted a technician, who would have used rational analysis of data and mathematical calculations, they would have got the same exact instruction. Moreover, the technician's response would have been even more intelligible, clear, and straightforward, far from the shifty, oblique language of oracles. In other words, there is no apparent reason to define the guidance of a professional and by extension of an intelligent person as being in any way inferior to divine oracular pronouncements. So why, Maximus asks, do some people prefer divination over human deliberation? This question is still strikingly valid-we need only think of the controversies between 'official' and 'alternative' explanations in medicine, economics, and the natural sciences. This inquiry goes back at least to Carneades, an academic-skeptic philosopher who first formulated the argument opposing divinatory to technical-specialistic skills, often employed in the debates between Stoics and Platonists (cf. Cic. Div. 2.3.9).

In Maximus's text, the problem of the relation between human expertise and divination is further compounded by the fact that he establishes a similarity between divine and human intellect (Max. Or. 13.2): just like divine intellect is not always right, human intellect is not always wrong. His argumentative strategy thus consists in downgrading divine intellect while boosting human rationality, which always strives toward perfection: human and divine intellect meet midway, where they support and complement each other. Mistakes in divination can be ascribed to the fallibility and lack of omniscience of divine intellect. Maximus admits that describing the divine intellect as faulty and imprecise is extremely controversial-almost blasphemous-from both an ontological and a theological perspective (and all the more so for a Platonist). It implies indeed breaking down the rigid barrier postulated between contingence and transcendence, while placing human and divine mind in the same ontological dimension. This solution mirrors the ethical precept, although intended in a mere metaphorical sense, of 'becoming like god', founded on the exegesis of Plato's Theaetetus 176a-b and widespread in Platonist and Pythagorean circles of the age. In To Become a God, anthropologist Michael Puett (2002) focuses exactly on processes of divinization in fourth-century вС Chinese theological-metaphysical systems. Nevertheless, in the material analyzed by Puett, 
differently from the Greco-Roman system, divinized human beings reach for a position of control over the entire cosmos.

For Maximus, the union of god's divination (mantikê theou) and human intelligence (anthrôpou nous) is based on the interconnection of all cosmic elements, visible and invisible, material and immaterial, which is the most perfect musical harmony - an idea that finds an interesting parallel in Chinese cosmological theories from the second century BC (cf. Max. Or. 13.5.20; Bodde 1981). Comparative analysis between Chinese and Graeco-Roman classical divinatory systems can be found in Dario Sabbatucci (1989) and G. E. R. Lloyd (1996), with the latter focusing as well on Greek and Chinese ideas of science.

The unusual perspective proposed by Maximus, which impairs the axiomatic distinction between gods and humans, is a noteworthy example of how ontological conceptions and divinatory theories are deeply interconnected. Maximus's view is at any rate at odds with the deceptive, trickster-like attitude of the gods in the Homeric poems examined by Almqvist in this issue. For Maximus, the divine intellect, far from having misleading or malevolent intentions, is simply fallible and deficient, but 'innocent' and 'inculpable' (anaitios) for anything bad-a definition fully in line with the Platonic tenet that the god is never responsible for evil. While Maximus admits that the god lacks absolute knowledge of contingent realities, the idea that a deity might purposely disorient or fool human beings would be simply inadmissible. This stance resonates with Martin Holbraad's (2012) theory expressed in his work on Afro-Cuban Ifá divination: divination is true by definition, and anthropologists should interpret it as it is, which means as a reliable set of practices that allow the disclosure of truth in a given context.

The complex nature of Maximus's explanation, based on multiple causal factors (providence, fate, fortune, individual responsibility), is antithetical to Epictetus's Stoic monistic-materialistic worldview. Maximus uses effective analogies to account for two interacting processes: on the one hand, the divine mind 'writes' and 'designs' the cosmic events; on the other, the human mind 'reads' or 'redesigns' them. The world, Maximus says, is like an immense engine: the god is the engineer, human beings are its parts, and divination is the technical knowledge that helps us predict how this machine will behave. According to another analogy, the universe is like a military campaign: the god is the commander, human beings are the soldiers, life is a war, and divination is the military art that helps us, the fighters, to plan our battles (cf. Max. Or. 13.4).

Maximus's allegories suggest that rational prediction and divination are similar by virtue of one single law on which they are both founded: fate (also translated as 'destiny' or 'necessity'). Maximus asks the question: "What is destiny" (peprômenê)? What is its nature (physis) and essence (ousia)? So what is the ontological status of fate? This is not a deterministic, inescapable, all-encompassing rule. On the contrary, fate determines only the causal 
relation between human choices and their consequences-hence, the definition of 'conditional fate' (Opsomer 2014) created by modern scholars (see also Sharples 2003). ${ }^{14}$ Divination, in this perspective, is a sort of logical-rational knowledge shared by humans and gods alike: based on the rational law of fate, it allows the outcomes of given predicaments to be inferred. Divination works precisely because it is entangled within all cosmic elements. Therefore, in order to understand its functioning, it is necessary to understand the laws that regulate the universe (Max. Or. 13.6).

There is some sort of division of competences between human and divine intellect for Maximus. Gods as well as inspired, semi-divine individuals (daimonioi) can predict events determined by necessity (anankê) (Max. Or. 13.5.6), such as natural phenomena like rainfall, earthquakes, volcanic eruptions. Nevertheless, only the supreme god, the 'divine intellect', can predict human behavior, which is determined by free will and therefore in our power. God is the only one who can scrutinize our soul and intentions, and inspect the real and innermost cause (aitia) of our actions (Max. Or. 13.5) - an argument in contrast with Epictetus's idea that divination cannot predict human actions. In Maximus's view, the world is predictable to a certain extent, since universal forces (fate and divine providence) never get to affect or threaten individual freedom. The lecture ends with a similitude between Socrates and Apollo, who perform the same art-a perfect closure for a text that strives all along to prove the consonance between human and divine intellect, and between philosophical and prophetic virtues (Max. Or. 13.9.1-25).

Maximus shares with Epictetus the image of the 'inner prophet'. In Orations 8-9, dedicated to the notion of Socrates's daimonion, Maximus states that, just like Socrates, wise human beings are guided through the difficulties of life by an inner voice, that is, the daemon that dwells within us. Daemons also exist independently from human bodies and offer their service as intermediaries between gods and humans (Max. Or. 8.8.1-10) by presiding over all divinatory practices (dreams, portents, flights of birds, oracles) (Max. Or. 8.1.1-18). ${ }^{15}$ Their ontological status is intermediate between humans (mortal and subject to passions) and gods (immortal, omniscient, and impassible). They are attributed the essential ontological-cosmological function of granting the harmonious interconnection of all cosmic parts. It is interesting to note that Descola's (2014: 276) definition of analogism similarly presupposes an arrangement of beings in an orderly scala naturae, an artificial order created by humans, hiding the original, chaotic nature of the world. ${ }^{16}$ On the contrary, our three philosophers seem to be better represented by William Matthews's (2017) theory of homologism, which presupposes instead that the world is per se ordered and rational.

Maximus draws the existence of daemons from the Homeric poems, where humans and gods (Athena, Hera, Apollo, Eris) live and fight side by side (cf. 
Max. Or. 8.6.11-12). For later interpreters, like Maximus himself, the fallible, capricious, and deceptive nature of the gods in epic literature (which Almqvist analyzes in the present issue) is irreconcilable with their status. On this basis, Platonists conceived Homeric gods as demi-gods, as 'daemons in disguise'. Compared to Oration 13, Maximus's Oration 8 is much more pessimistic about human cognitive possibilities and the structure of worldly reality. It argues that, due to our limited cognitive capabilities, we are in need of oracles as indispensable sources of knowledge and moral norms. Not only is our rational power (logismos) limited, but also worldly reality is confused and chaotic, governed by chance (tychê) - a cosmic power deemed almost irrelevant in Oration 13 (cf. Max. Or. 8.3.1-10).

Maximus's account has numerous points of contact with lines of research in modern anthropology, especially as concerns his emphasis on the psychological assurance that divination provides and the multi-layered ontology on which he founds his theory of divination. Exploring the reasons behind the preference for divination over more standard means of knowledge acquisition is studied by contemporary anthropologists as well. Pascal Boyer (2020) sees the success of divination linked to the lack of alternative avenues of knowledge acquisition: divination works inasmuch as it is the only available means to obtain some form of reliable advice in a given circumstance. This might be the case in antiquity, but people resort to diviners even in cases for which expert advice is available.

\section{Conclusions}

The orations analyzed in this article, attesting to and critically examining ancient divinatory habits and beliefs, have allowed us to shed light on how divination was conceptualized in the first centuries AD with regard to its ontological foundation and practical efficacy. The views of intellectuals perhaps differ to some degree from those of average consultants in terms of content or theoretical sophistication. Nevertheless, in this historical period, the desire to receive divine guidance and assistance in matters of everyday life is widespread at all levels of society (Belayche 2007; Sfameni Gasparro 1993). Moreover, as the texts analyzed have shown, divination has not only a predictive-diagnostic function but also, and especially, a prescriptive one. Accordingly, it is envisioned as a source of knowledge that helps human beings to orient themselves into the material reality and to undertake a proper course of action.

Dio endorses a view according to which the gods know and communicate the truth, but they do so in their own language. Therefore, if humans do not know how to make good use of gods' words, then they should not approach them. Divination is a reliable system of knowledge that discloses future facts. 
Nevertheless, unfit persons (e.g., non-philosophers) will be unable to understand and make good use of the predictions or prescriptions received. For Dio, the ontological status of divination is that of a divine gift, coming from a completely other ontological dimension, and therefore a difficult, even dangerous tool to handle. Epictetus stresses even more the importance of philosophical knowledge-and chiefly self-knowledge-for using divination correctly. Being aware of the ontology behind divination is essential for divinatory consultation: responses concern only what is determined by the law of fate or destiny, while individual choices are outside the domain of divination and are in our own hands. The relation between events is governed by fate and orchestrated by the divine mind, always with our good at stake. Divination allows us to know in advance about inescapable events and helps us be prepared to act virtuously. Finally, Maximus works out his own original solution to the problem of the interaction between contingency and transcendence. He upraises human intellect and downgrades the divine mind to the point that they are conjoined in the same ontological position and share similar capabilities and limits. This is a bizarre, extreme solution-one that overthrows the ontological distinction between the divine and the human dimension, which is taken for granted by Dio and Epictetus.

From the analysis above, three conclusions may be drawn. First, all of our authors are convinced that divination is a way to access truth. It is unanimously conceived as a reliable and accurate means of knowledge acquisition, but only if one knows how to make a good use of it. Their god is like Orula in Ifá divination: he never lies (Holbraad 2012). Divination for the thinkers of the first centuries $\mathrm{AD}$ is not an activity managed by a group of capricious beings, willing to deceive and baffle humans. With the sole exception of some skeptical thinkers, such as Lucian of Samosata or Oenomaus of Gadara, great trust is placed in revelations, epiphanies, and prophecies, on the basis of which entire theological and political systems are developed, and on the grounds of which the momentous confrontation between pagans and Christians takes place. ${ }^{17}$

Second, the texts discussed here reveal that every theory of prediction implies broader considerations that are invested in the nature and structure of the whole universe, both in ontological and cosmological terms. ${ }^{18}$ This examination has proven that any theory of divination generates a precise worldview, while ontology, vice versa, is founded on a specific conception of how the cosmic forces and classes of beings are organized. Dio defines the connection between contingency and transcendence in dialogical-hermeneutic terms: human beings can receive useful messages from the gods, but it is their responsibility to interpret them correctly. For the Stoic Epictetus, the law of fate is the norm whereby the interaction between transcendence and contingency is regulated; it also defines the events that can be foreseen by divination and determines the moral value of prediction. Maximus instead employs divination 
to create an abstract 'divinatory mind', in which transcendent-divine and contingent-human factors merge and cooperate.

Third, exploring the writings of Dio, Epictetus, and Maximus has helped us to appreciate key Graeco-Roman conceptions on divination and to shed light on the "specific mappings of the number, nature, and interconnections among fundamental categories of being” that, according to Michael Scott (2007: 4), lie at the core of an ontologically centered anthropology. Moreover, Dio, Epictetus, and Maximus place human agents at the center of their prophetic theories and their ontology: humans, morally responsible agents, are always accountable for their own choices, even when they decide to follow the precepts disclosed by divination. Of course, there are also clear differences between the late-ancient philosophical approach and modern anthropological studies. One need only look at the notion of divine infallibility, which is clearly not taken for granted by modern anthropologists. The same goes for the notion of 'truth', which is not defined in an absolute, philosophical sense, as well as for that of 'ontology' itself, or for the different ways in which the interaction between human beings and gods is envisioned.

Dio, Epictetus, and Maximus formulated methodological and theoretical questions on divination that are similar to those of modern scholars in anthropology-especially in terms of the interaction between divination and ontology, on which the present collection of studies is centered. Scott's (2007) distinction between mono- and poly-ontology is particularly useful to capture a core distinction between the three authors. The mono-ontological system coincides with Epictetus's typically Stoic idea of the cosmos being regulated by one single divine-material principle (the pneûma), which encompasses all the world's elements and binds all of its parts together, while embracing the very functioning and outcomes of divination. Maximus's Platonic perspective of a graduated cosmos, in which beings are hierarchically arranged according to their proper ontological status and nature, is indicative instead of a poly-ontological system. This categorization relates to the gap between transcendence and contingency that lies at the basis of all the divinatory theories analyzed-a gap that divination itself is supposed to fill. While for Epictetus transcendence and contingency are two interrelated factors, for Dio and Maximus the distance between the material-visible and the spiritual-intelligible world is all the more evident.

As regards the transmission of knowledge involved in divination, all three philosophers only focus on, and side with, the consultant, without much consideration of the role played by the diviner. They all assume that diviners talk on behalf of the gods and pronounce true statements about the future. This particular aspect of their approach helps us to focus on an 'ideal' set of cosmological and ontological premises on which basis divinatory theories are developed. Dio, Epictetus, and Maximus situate their reflection on divination within 
wider ontological and cosmological views and anchor them to universally valid instances and notions. They all assume the existence of a provident god who cares for and communicates with humankind, and who knows the most hidden recesses of our souls-a knowledge he does not seem to want to share with us.

\section{Acknowledgments}

I would like to express my gratitude to William Matthews for inviting me to take part in this wonderful conference, and to all the speakers and participants for the stimulating discussions and enriching exchanges. Thanks are also due to Hans Steinmüller.

Elsa Giovanna Simonetti is an FWO Postdoctoral Fellow at KU Leuven. After obtaining her joint PhD from the University of Padova and KU Leuven in 2016, she was a Newton International Fellow at Durham University (2017-2019). Her book A Perfect Medium? Oracular Divination in the Thought of Plutarch (2017) analyzes the interactions between philosophy and divinatory theories in the works of Plutarch of Chaeronea. Her main research interests lie in the interactions between religious and philosophical doctrines in later antiquity. She is now editing a book titled 'Ancient Revelation: Divination, Prophecy and Epiphany', based on an international conference she organized in Durham. E-mail: elsagiovanna.simonetti@kuleuven.be

\section{Notes}

1. For more on this matter, see also the articles by Almqvist and Matthews in this special issue.

2. For a recent discussion on the category of 'personal religion' in antiquity, see Kindt (2015). The notions of 'individuation' and 'individualization' are analyzed in Rosenberger (2013).

3. For information on classical abbreviations used in this article, see https:// oxfordre.com/classics/page/ocdabbreviations/abbreviations. Unless otherwise indicated, translations of non-English text are my own.

4. The need emerged to discipline divinatory practices in order to safeguard the dignitas and maiestas of the emperor and of the Roman people. A law reported in the Sententiae of Iulius Paulus sought to punish those who asked diviners about the life of the emperor or about state affairs. The penalty for this crime was death, for both the consultant and the seer. 'False prophets' who pretended to be divinely inspired were subject to corporal punishment 
and permanent banishment from the community (Sent. 5.21.3). Similar laws appeared in the codices in force during the age of the Empire, from Augustus to Diocletian and Justinianus (cf. Cod. Just. 9.8.2.).

5. Modern debates in anthropology regarding the epistemological difference between modes of cognition were anticipated by Evans-Pritchard ([1937] 1976) and have been developed more recently by Sperber (1982) and Holbraad (2012). In the present issue, the article by William Matthews focuses on how rational human faculties (i.e., reflection and intuition) are employed in divinatory practices.

6. For other such positive references to oracles and divination, see Dio Chrys. $4.72 ; 5.24-25 ; 13.7 ; 17.16$.

7. See in this regard the very fruitful line of research-embraced, among others, by David Zeitlyn (2001) and Peter Struck (2004) — that equates text divination to literary criticism.

8. For more on this work, see Gabor (2014). For the afterlife of Epictetus, see Simonetti (2019).

9. It is important to remember that Stoicism was the most supportive philosophical school with respect to the utility of divination.

10. A notorious example of such theorems is "If you are born under the Dog-star, you will not die at sea." Also see Cic. De fato 11-16. The Stoics conceived divination as founded on a robust scientific apparatus. They developed predictive theorems based on observation and a collection of connections between events. Divinatory theorems do not connect causes with effects, nor do they state any causal relation in a wider sense. The connection between signs and future facts is based not on causality, but on a regular pattern discovered through long and repeated observations of phenomena.

11. For a comprehensive account of these debates, see Eliasson (2008).

12. Note the recurrence of the verb chrêsthai in its double meaning, just as in Dio Chrysostom.

13. See the thorough introduction to this oration in Trapp (1997: 115-116).

14. Other passages on this topic in ancient sources include Cic. De fato, Ps. Plut. De fato, Apul. De Plat. 1.12, and Alc. Didasc. 179.2-3.

15. This conception goes back to Plat. Symp. 202e and was commonly assumed in the age of Maximus (cf. Apul. De deo Socr. 6.133).

16. See also Max. Or. 9.2.2: harmonia teleôtatê. In Oration 9, interestingly, Maximus insists on asking what the ontological status and nature of the daemons is (daimonôn ousia) - a complex yet fundamental question to answer. One of the best metaphors created by Maximus is that of the middle note in a harmonic scale between two extremes (hê mesê) (see Max. Or. 9.1.25).

17. Some useful recent references to this large field of analysis and debate are Aune (1983), Carrara and Männlein-Robert (2018), Fox (1987), Nieto Ibáñez (2010), and Sfameni Gasparro (2016).

18. Contemporary anthropologists also employ cosmological frameworks to explain divinatory systems (cf. Holbraad 2012: 125-130), and when they do not presuppose an explicit cosmology (cf. Zeitlyn 2001, 2012). 


\section{References}

Aune, David E. 1983. Prophecy in Early Christianity and the Ancient Mediterranean World. Grand Rapids, MI: Wm. B. Eerdmans Publishing.

Belayche, Nicole. 2007. "Les dieux 'nomothètes': Oracles et prescriptions religieuses à l'époque romaine impériale” [Gods 'nomothetes': Oracles and religious prescriptions at the time of the Roman Empire]. Revue de l'histoire des religions 2: 171-191. https://doi.org/10.4000/rhr.5254.

Bobzien, Susanne. 1998. "The Inadvertent Conception and Late Birth of the FreeWill Problem.” Phronesis 43 (2): 133-175.

Bodde, Derk. 1981. "The Chinese Cosmic Magic Known as Watching for the Ethers." In Essays on Chinese Civilization, ed. and trans. Charles Le Blanc and Dorothy Borei, 351-372. Princeton, NJ: Princeton University Press.

Boyer, Pascal. 2020. "Why Divination? Evolved Psychology and Strategic Interaction in the Production of Truth.” Current Anthropology 61 (1): 100-123. https://doi.org/10.1086/706879.

Brown, Peter. 1971. "The Rise and Function of the Holy Man in Late Antiquity." Journal of Roman Studies 61: 80-101. https://doi.org/10.2307/300008.

Carrara, Laura, and Irmgard Männlein-Robert, eds. 2018. Die Tübinger Theosophie [The Tübingen theosophy]. Stuttgart: Hiersemann.

Cohoon, J. W., trans. 1932. Dio Chrysostom: Discourses 1-11. Cambridge, MA: Harvard University Press.

Corcoran, Thomas H., trans. 1971. Seneca: Natural Questions. Volume I: Books 1-3. Cambridge, MA: Harvard University Press.

Descola, Philippe. 2013. Beyond Nature and Culture. Trans. Janet Lloyd. Chicago: University of Chicago Press.

Descola, Philippe. 2014. "Modes of Being and Forms of Predication." HAU: Journal of Ethnographic Theory 4 (1): 271-280. https://doi.org/10.14318/hau4.1.012.

d'Hoine, Pieter, and Gerd Van Riel, eds. 2014. Fate, Providence and Moral Responsibility in Ancient, Medieval and Early Modern Thought. Leuven: Leuven University Press.

Eliasson, Erik. 2008. The Notion of That Which Depends on Us in Plotinus and Its Background. Leiden: Brill.

Evans-Pritchard, E. E. (1937) 1976. Witchcraft, Oracles and Magic among the Azande. Abr. Eva Gillies. Oxford: Clarendon Press.

Flower, Michael Arryah. 2008. The Seer in Ancient Greece. Berkeley: University of California Press.

Fox, Robin Lane. 1987. Pagans and Christians. New York: Knopf.

Gabor, Gary. 2014. "When Should a Philosopher Consult Divination? Epictetus and Simplicius on Fate and What Is Up to Us.” In d'Hoine and Van Riel 2014, 325-340.

Holbraad, Martin. 2012. Truth in Motion: The Recursive Anthropology of Cuban Divination. Chicago: University of Chicago Press.

Kindt, Julia. 2015. "Personal Religion: A Productive Category for the Study of Ancient Greek Religion?” Journal of Hellenic Studies 135: 35-50. 
Lloyd, G. E. R. 1996. Adversaries and Authorities: Investigations into Ancient Greek and Chinese Science. Cambridge: Cambridge University Press.

Matthews, William. 2017. "Ontology with Chinese Characteristics: Homology as a Mode of Identification.” HAU: Journal of Ethnographic Theory 7 (1): 265-285. http://dx.doi.org/10.14318/hau7.1.020.

Nieto Ibáñez, Jesús M. 2010. Cristianismo y profecías de Apolo: Los oráculos paganos en la Patrística griega (siglos II-V) [Christianity and the prophecies of Apollo: Pagan oracles and Greek patristics (centuries II-V)]. Madrid: Editorial Trotta.

Oldfather, W. A., trans. 1925. Epictetus: Discourses, Books 1-2. Cambridge, MA: Harvard University Press.

Oldfather, W. A., trans. 1928. Epictetus: Discourses, Books 3-4. Fragments: The Encheiridion. Cambridge, MA: Harvard University Press.

Opsomer, Jan. 1997. "Favorinus versus Epictetus on the Philosophical Heritage of Plutarch: A Debate on Epistemology." In Plutarch and His Intellectual World, ed. Judith Mossman, 17-39. Swansea: Classical Press of Wales.

Opsomer, Jan. 2014. “The Middle Platonic Doctrine of Conditional Fate.” In d'Hoine and Van Riel 2014, 137-167.

Puett, Michael J. 2002. To Become a God: Cosmology, Sacrifice, and Self-Divinization in Early China. Cambridge, MA: Harvard University Press.

Rosenberger, Veit, ed. 2013. Divination in the Ancient World: Religious Options and the Individual. Stuttgart: Franz Steiner Verlag.

Sabbatucci, Dario. 1989. Divinazione e cosmologia: Scrivere e leggere il mondo [Divination and cosmology: Reading and writing the world]. Milan: Il Saggiatore.

Scott, Michael. 2007. The Severed Snake: Matrilineages, Making Place, and a Melanesian Christianity in Southeast Solomon Islands. Durham, NC: Carolina Academic Press.

Sfameni Gasparro, Giulia. 1993. "Oracolo, divinazione e profetismo nel mondo greco-romano da Augusto alla fine del II secolo” [Oracle, divination, and prophecy in the Graeco-Roman world from Augustus to the end of the second century]. Ricerche storico-bibliche 5: 11-42.

Sfameni Gasparro, Giulia. 2016. “Gli ‘oracoli teologici’ fra pagani e cristiani: Temi e problemi a confronto" ['Theological oracles' between pagans and Christians: Confronting themes and problems]. In Theologische Orakel in der Spätantike [Theological oracles in late antiquity], ed. Helmut Seng and Giulia Sfameni Gasparro, 329-350. Heidelberg: Winter Verlag.

Sharples, Robert W. 2003. "Threefold Providence: The History and Background of a Doctrine.” In Ancient Approaches to Plato's Timaeus, ed. Robert W. Sharples and Anne Sheppard, 107-127. London: University of London.

Simonetti, Elsa Giovanna. 2019. "Plutarch and the Neoplatonists: Porphyry, Proklos, Simplikios.” In Brill's Companion to the Reception of Plutarch, ed. Sophia Xenophontos and Katerina Oikonomopoulou, 136-153. Leiden: Brill.

Sperber, Dan. 1982. "Apparently Irrational Beliefs.” In Rationality and Relativism, ed. Martin Hollis and Steven Lukes, 149-180. Cambridge, MA: MIT Press.

Struck, Peter T. 2004. Birth of the Symbol: Ancient Readers at the Limits of Their Texts. Princeton, NJ: Princeton University Press. 
Struck, Peter T. 2016. Divination and Human Nature: A Cognitive History of Intuition in Classical Antiquity. Princeton, NJ: Princeton University Press.

Trapp, M. B., ed. and trans. 1997. Maximus of Tyre: The Philosophical Orations. Oxford: Clarendon Press.

Zeitlyn, David. 2001. "Finding Meaning in the Text: The Process of Interpretation in Text-Based Divination." Journal of the Royal Anthropological Institute 7 (2): 225-240. https://doi.org/10.1111/1467-9655.00060.

Zeitlyn, David. 2009. "Understanding Anthropological Understanding: For a Merological Anthropology.” Anthropological Theory 9 (2): 209-231.

Zeitlyn, David. 2012. "Divinatory Logics: Diagnoses and Predictions Mediating Outcomes." Current Anthropology 53 (5): 525-546. 